\title{
A Specific Inhibitor of Calcium/Calmodulin-Dependent Protein Kinase-II Provides Neuroprotection against NMDA- and Hypoxia/ Hypoglycemia-Induced Cell Death
}

\author{
Iradj Hajimohammadreza, ${ }^{2}$ Albert W. Probert, ${ }^{1}$ Linda L. Coughenour, ${ }^{1}$ Susan A. Borosky, ${ }^{1}$ Frank W. \\ Marcoux, ${ }^{1}$ Peter A. Boxer, ${ }^{1}$ and Kevin K. W. Wang ${ }^{2}$ \\ 'Department of Neuroscience Pharmacology and 'Laboratory of Neuro-biochemistry, Parke-Davis Pharmaceutical \\ Research, A Division of Warner Lambert Company, Ann Arbor, Michigan 48105
}

\begin{abstract}
Calcium/calmodulin-dependent protein kinase-II (CamK-II) is a major neuronal protein which plays a significant role in the cellular process of long-term potentiation (LTP), and vesicular release of neurotransmitters. Here, we show that $\mathrm{KN}-62$, 1-[ $N$, O-bis(5-isoquinolinesulfonyl)- $\mathrm{N}$-methyl-L-tyrosyl]-4-phenylpiperazine, a specific cell-permeable inhibitor of CamK-II substantially protected neurons from (1) acute NMDA toxicity and (2) hypoxia/hypoglycemia-induced neuronal injury in fetal rat cortical cultures. KN-62 did not directly inhibit glutamate, kainate, $\alpha$-amino-3-hydroxy-5methyl-4-isoxazolepropionate (AMPA), glycine, or [piperidyl-3,4-(N)]-( $N$-[1-(2-thienyl)cyclohexyl]-3,4-piperidine) (TCP) binding to rat brain membranes. Finally, KN-62 significantly reduced cellular calcium accumulation following either NMDA challenge or hypoxia/hypoglycemia insult. Our results show that CamK-II plays a key role in mediating some of the biochemical events leading to cell death following an acute excitotoxic insult.
\end{abstract}

[Key words: NMDA, hypoxia/hypoglycemia, calcium/calmodulin-kinase-Il, intraneuronal calcium, KN-62, spectrin]

Glutamate, the major excitatory amino acid (EAA) in the CNS has been implicated in neuronal injury associated with cerebral ischemia, epilepsy, and chronic neurodegenerative disorders (Meldrum and Garthwaite, 1990). Glutamate receptors have been classified as either ionotropic or metabotropic (Meldrum and Garthwaite, 1990). The recent molecular cloning of the subunits for the ionotropic glutamate receptors has confirmed the original classification of AMPA, kainate and NMDA receptors. These receptors are composed of homo- or heteromeric combinations of subunits (GluR1-4 for AMPA/kainate receptors, GluR5-7 and KAl-2 for kainate receptors, and NMDAR 1 and NMDAR2A-D for NMDA receptor) (Nakanishi, 1992; Seeburg, 1993). Activation of the NMDA subtype of the glutamate receptor has been shown to be the major contributor to cell death in cortical cell cultures subjected to acute excitotoxicity or oxygen and glucose deprivation (Choi, 1987, 1988; Goldberg and Choi, 1993; Hartley et al., 1993). The early biochemical feature of NMDA-induced excitotoxicity in neurons is the disturbance in ionic balance triggered by calcium and sodium influx through

\footnotetext{
Received Sept. 15, 1994; revised Dec. 14, 1994; accepted Dec. 28, 1994.

Correspondence should be addressed Iradj Hajimohammadreza, Laboratory of Neuro-biochemistry, Parke-Davis Pharmaceutical Research, A Division of Warner Lambert Company, 2800 Plymouth Road, Ann Arbor, MI 48105.

Copyright (C) 1995 Society for Neuroscience 0270-6474/95/154093-09\$05.00/0
}

the NMDA receptor/channel complex (Choi, 1987, 1988; Marcoux et al., 1990; Goldberg and Choi, 1993; Hartley et al., 1993; Weber et al., 1993). One consequence of such ionic imbalance is the activation/overactivation of many vital cellular enzymes (protein kinases and phosphatases, phospholipases and proteases), in particular those regulated by calcium followed by a cascade of both biochemical and physical changes (cytoskeletal breakdown) leading to neuronal death (Siman and Noszek, 1988; Saido et al., 1994).

One such enzyme, CamK-II, has an important role in decoding signals generated by neurotransmitters which raise intracellular free calcium $\left(\left[\mathrm{Ca}^{2+}\right]_{i}\right)$. CamK-II is highly enriched in neurons, both in the pre- and postsynaptic compartments where it is essential to neurotransmitter release and induction of LTP, respectively (Llinas et al., 1985; Malenka et al., 1989; Greengard, 1993). Recent studies have also linked CamK-II to regulation of both voltage-gated and ligand-gated ion channels, in particular those associated with glutaminergic neurotransmission (Greengard et al., 1991; Wang et al., 1991; Keller et al., 1992; Raymond et al., 1993; McGlade-McCulloh et al., 1993). CamKII is a scrinc-thrconine kinase activated by an increase in $\left[\mathrm{Ca}^{3+}\right]_{i}$ (bound to calmodulin) following an appropriate agonist stimulation, such as NMDA (Fukunaga et al., 1990, 1992). Once activated by the $\mathrm{Ca}^{2+} /$ calmodulin, $20-80 \%$ of the enzyme activity is maintained by its conversion to a $\mathrm{Ca}^{2+}$-independent form via autophosphorylation. This posttranslational modification of CamK-II is a rapid process in neurons and could be a key factor in its sustained catalytic activity (Rich et al., 1990; Yamamoto et al., 1992).

The main feature of this multifunctional kinase is phosphorylation of a number of substrate proteins, which mediate many of the actions of cellular second messengers. Several investigators have shown that phosphorylation of the AMPA/kainate receptor by protein kinases such as CamK-II, protein kinase $\mathrm{C}$ (PKC) or cAMP-dependent protein kinase (PKA) regulates its function in neurons (Greengard et al., 1991; Wang et al., 1991; Keller et al., 1992; McGlade-McCulloh et al., 1993; Raymond et al., 1993). The NMDA subtype of glutamate receptor is also modulated by phosphorylation in neurons (Chen et al., 1992; Kitamura et al., 1993). In all cases, glutamate receptor phosphorylation leads to a positive modulation on the receptor function maintaining synaptic excitability. The importance of CamKII in maintenance of synaptic excitability and also its extreme vulnerability in in vivo models of ischemia (Churn et al., 1992; Hanson et al., 1994) and in vitro excitotoxicity (Churn et al., 
1993) have led us to examine its potential contribution in EAAmediated cell death.

Therefore, to examine the role of CamK-II in EAA-mediated neurotoxicity in fetal rat cerebrocortical cultures, we used the CamK-II specific inhibitor KN-62 with proven cell permeability (Tokumitsu et al., 1990; Hidaka and Hagiwara, 1992). KN-62 competitively inhibits CamK-II with respect to calcium/calmodulin and has no inhibitory effect on PKA, PKC, myosin light chain kinase, or casein kinase-I (Tokumitsu et al., 1990; Hidaka and Hagiwara, 1992). KN-62 is not a calmodulin antagonist and is only effective on inhibiting the activity of CamK-II before its autophosphorylation. KN-62 has also been used previously as a specific inhibitor for CamK-II in various neuronal systems ( $\mathrm{Fi}$ gurov et al., 1993; Hack et al., 1993).

\section{Materials and Methods}

Chemicals. KN-62 was purchased from Seikagaku America; K252a (Nocardiopsis sp.), genistein, calphostin C (Cladosporium cladosporioids), compound 5 [2-hydroxyl-5-(2,5-dihydroxy-benzyl) aminobenzoic acid] and calmidozolium were purchased from LC laboratories. ${ }^{45} \mathrm{Ca}^{2+}$ was from ICN Biomedicals. Tissue culture media and serum were from GIBCO-Bethesda Research Labs. All other reagents were of analytical grade and purchased from Sigma Chemical Company.

Neuronal cultures. Cortical hemispheres sectioned from fetal rat (Sprague-Dawley) in their 18th day of gestation and were trypsin digested and triturated into single cell suspension. cells were pipetted into individual wells of poly-L-lysine-coated plates, yielding a final cell concentration of 200,000 cells $/ \mathrm{cm}^{3}$ using GIBCO Minimum Essential Medium (MEM; containing 10\% horse and 10\% fetal bovine serum; heat inactivated). Non-neuronal cell division was halted three days into culture by adding $25 \mu \mathrm{g} / \mathrm{ml}$ uridine and $10 \mu \mathrm{g} / \mathrm{ml} 5$-fluoro-2'-deoxyuridine. Feeding were performed as necessary with MEM with $10 \%$ horse serum. Experiments were performed on 17-21 d (postisolation) old neurons. Cultures were triple washed with MEM (serum free) with or without the test agents (inhibitors). NMDA was added directly to the culture media. After $30 \mathrm{~min}$ incubation at $37^{\circ} \mathrm{C}$, NMDA was washed by triple exchange with serum free MEM (+inhibitors). Final concentration of glucose in the MEM throughout the culture period was 30 mM.

Cell viability assay. Neuronal injury was assessed qualitatively by light microscopic examination of the phase contrast appearance of cultures. Quantitative assessments of neuronal injury were made using lactate dehydrogenase ( $\mathrm{LDH}$ ) release as a marker for membrane breakage and cell death (Koh and Choi, 1987). One day post experiment initiation, $25 \mu \mathrm{l}$ of culture medium was combined with $225 \mu \mathrm{l}$ of $0.1 \mathrm{~mm}$ potassium phosphate buffer containing $0.133 \mathrm{mg} / \mathrm{ml} \beta-\mathrm{NADH}$. Following a $20 \mathrm{~min}$ incubation at $37^{\circ} \mathrm{C}$, wells received $30 \mu$ l of sodium pyruvate $(2.39 \mathrm{~mm}$ in phosphate buffer, $\mathrm{pH} 7.5)$ and kinetic measurements (at $340 \mathrm{~nm}$ for $2 \mathrm{~min}$ ) were immediately performed using a Titertek Multiscan plate reader.

Calcium microspectrofluorimetry. Experiments were performed using a PTI Deltascan system (Princeton, NJ). Neurons were loaded with 2$4 \mu$ FURA-2 AM (Molecular Probes, Eugene OR) in buffer (in mM: $\mathrm{NaCl}, 137 ; \mathrm{KCl}, 2.6 ; \mathrm{Na}_{2} \mathrm{PO}_{4}, 8.1 ; \mathrm{MgCl}_{2}, 0.5 ; \mathrm{CaCl}_{2}, 0.9$; HEPES$\mathrm{NaOH}, 10$; glucose, 11 ; with $150 \mathrm{mg} / \mathrm{ml}$ bovine serum albumin, $\mathrm{pH}=$ 7.4) at room temperature for $1 \mathrm{hr}$ and rinsed in the same buffer without FURA-2 AM but with added glycine $(10 \mu \mathrm{M})$ for at least $15 \mathrm{~min}$. A single cell was observed ( $40 \times$ objective, n.a. 1.3) and alternatively illuminated at 340 and $380 \mathrm{~nm}$. Photometric measurements at $510 \mathrm{nM}$ were made continuously at a rate of $5 \mathrm{~Hz}$. Drugs were bath applied by superfusion $(1 \mathrm{ml} / \mathrm{min})$. Tetrodotoxin $(300 \mathrm{~nm})$ was added in the superfusion media to reduce spontaneous calcium oscillations. Results were quantified by measuring the area under the curve of the fluorescence ratio $\left(F_{340} / F_{380}\right)$ versus time waveform; for each cell the second $1 \mathrm{~min}$ challenge with $25 \mu \mathrm{M}$ NMDA was used to normalize the results. Each neuron was challenged three times with $25 \mu \mathrm{M}$ NMDA $(1 \mathrm{~min})$, and waveforms from the second and third challenges were used for area quantification.

Receptor binding assay. Well-washed rat brain membranes from a lysed buffy coat fraction were prepared according to the method of Kishimoto et al (1981). ${ }^{3} \mathrm{H}$-glutamate and ${ }^{3} \mathrm{H}$-glycine binding were carried out in $50 \mathrm{~mm}$ Tris acetate buffer $(\mathrm{pH} 7.4)$. Brain membranes (200-
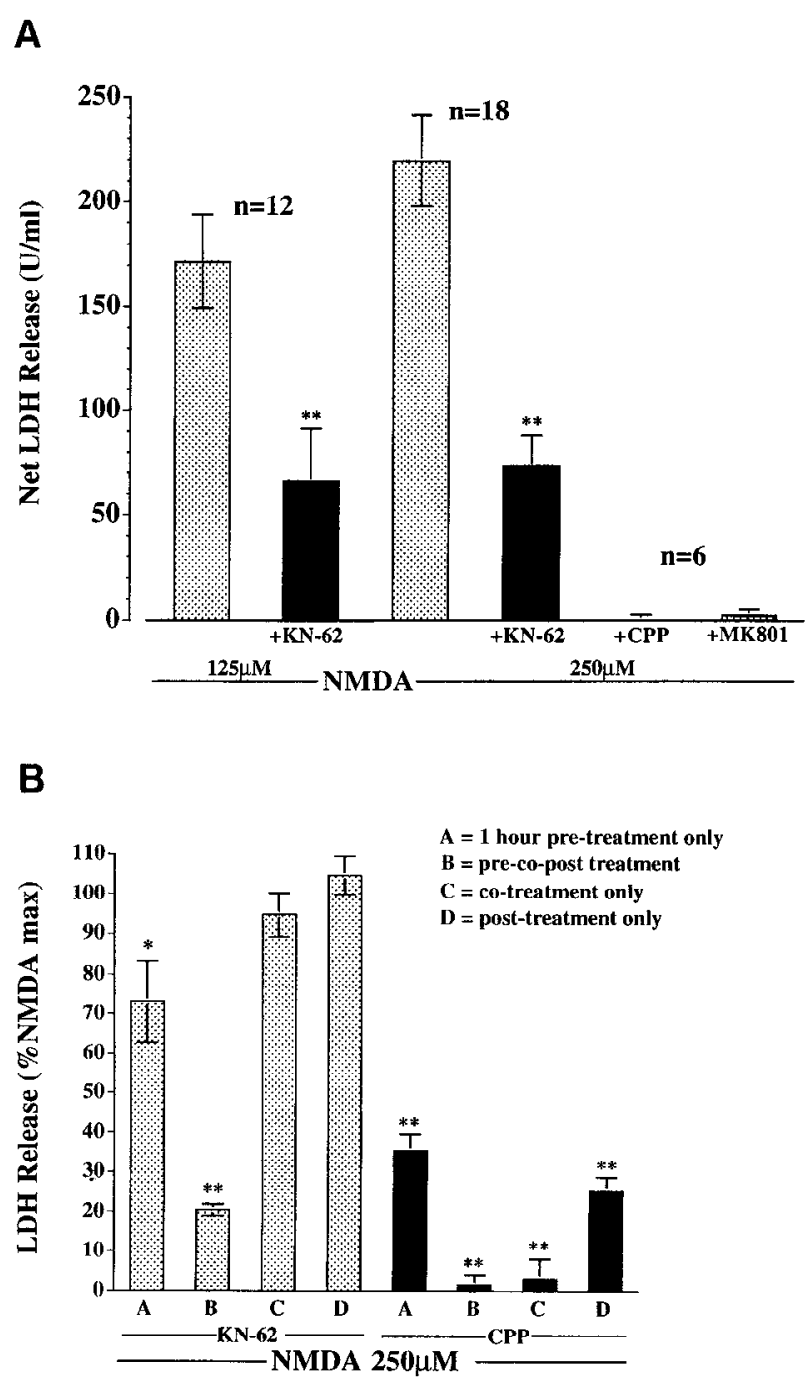

Figure 1. Inhibition of NMDA-induced toxicity by KN-62 (5 $\mu \mathrm{M})$, CPP $(100 \mu \mathrm{M})$ and MK801 $(1 \mu \mathrm{M})$. A, Net LDH release $24 \mathrm{hr}$ after a $30 \mathrm{~min}\left(\right.$ at $\left.37^{\circ} \mathrm{C}\right)$ challenge with NMDA. Data are means \pm SD. $B$,

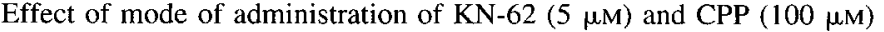
on the degree of protection against NMDA. These data are means \pm SD of five separate experiments. $C$, Western blot analysis of proteins extracted from culture conditions shown in $A$ with a monoclonal antispectrin antibody (Affiniti laboratories, U.K.). Solid arrow shows intact spectrin $(240 \mathrm{kDa})$ and open arrowheads show proteolytic breakdown fragments of spectrin (150 and $145 \mathrm{kDa}$ ), molecular weight markers $(\mathrm{kDa})$ are shown on the left. The blot is a typical representative of at least four different analyses. $D$, A representative phase contrast photomicrograph of cerebrocortical mixed cultures taken from a random field at the end of treatments shown. Photomicrograph of the KN-62 pretreated neurons with NMDA challenge shows only the live neurons, which have normal morphology. There were also dead neurons in these cultures. NMDA, $250 \mu \mathrm{M} ; \mathrm{KN}-62(K N), 5 \mu \mathrm{M}$. ${ }^{* *}, p \leq 0.0001 ;{ }^{*}, p \leq$ 0.001 , Student's $t$ test.

$400 \mu \mathrm{g})$ were incubated with ${ }^{3} \mathrm{H}$-glutamate $(2 \mathrm{nM})$ and ${ }^{3} \mathrm{H}$-glycine $(20$ $\mathrm{nM})$ for $30 \mathrm{~min}$ on ice. Specific binding for ${ }^{3} \mathrm{H}$-glutamate $(80 \%)$ was defined as that displaced in the presence of $0.1 \mathrm{~mm} \mathrm{NMDA}$ and for ${ }^{3} \mathrm{H}-$ glycine $(65 \%)$ as that displaced by $0.1 \mathrm{~mm} 5,7-$ dichlorokynurenic acid. ${ }^{3} \mathrm{H}$-TCP ( $2 \mathrm{nM}$ ) binding was carried out as described above except the incubations were for $1 \mathrm{hr}$ at room temperature in $20 \mathrm{mM}$ HEPES-KOH buffer (pH 7.4). ${ }^{3} \mathrm{H}$-AMPA (10 nM) and ${ }^{3} \mathrm{H}$-kainate $(20 \mathrm{nM})$ binding was carried out in a $50 \mathrm{~mm}$ Tris- $\mathrm{HCl}$ buffer ( $\mathrm{pH} 7.4$ ) containing either 10 mM potassium thiocyanate for ${ }^{3} \mathrm{H}$-AMPA or $20 \mathrm{mM} \mathrm{CaCl}_{2}$ for ${ }^{3} \mathrm{H}$-kainate for $1 \mathrm{hr}$ on ice. Specific binding was defined as that displayed in the 
The Journal of Neuroscience, May 1995, 15(5) 4095

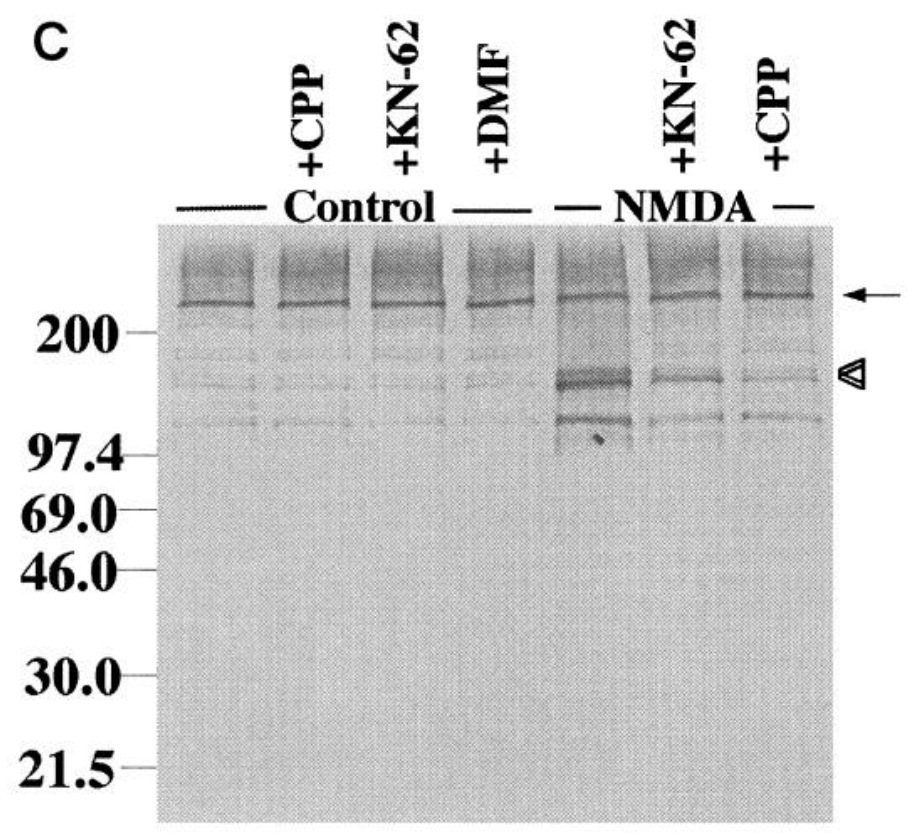

D
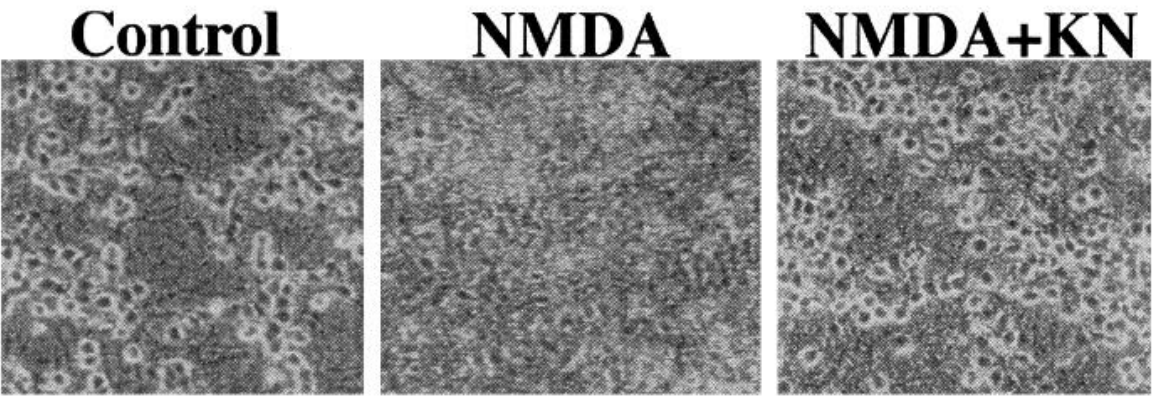

Figure I. Continued.

presence of $1 \mathrm{~mm}$ glutamate. Filtration was done with a Brandell MB$48 \mathrm{R}$ cell harvester through Whatman GF/B filters. Radioactivity was quantified by liquid scintillation counting.

Electrophoresis and Western blotting. Proteins were analyzed by SDS-PAGE according to the method of Laemmli (1970). After electrophoresis, proteins were blotted onto PVDF membrane (Towbin et al., 1979 ) and blocked with 5\% nonfat milk. Blots were incubated overnight in primary antisera and then one hour with biotinylated secondary antiserum. The immunoreactivity was visualized by alkaline phosphataseconjugated streptavidin (Amersham). Anti-spectrin ( $\alpha$-fodrin; monoclonal) was purchased from Affiniti Laboratories, U.K.

${ }^{45} \mathrm{Ca}^{2+}$ accumulation studies. These were carried out according to the method of Birrell et al. (1993). Briefly, cells were washed three times with $\mathrm{Mg}^{2+}$-free HBSS containing $2.5 \mathrm{mM} \mathrm{Ca}^{2+}$, and incubated with the test drugs for one hour. ${ }^{45} \mathrm{Ca}^{2+}(2 \mu \mathrm{Ci} / \mathrm{ml})$ was present $20 \mathrm{~min}$ prior to, during NMDA exposure $\left(30 \mathrm{~min}\right.$ at $\left.37^{\circ} \mathrm{C}\right)$. Cells were washed three times with saline and lysed with distilled water, and ${ }^{45} \mathrm{Ca}^{2+} \beta$ emissions in the intracellular contents were counted by scintillation spectroscopy.

Oxygen/glucose (hypoxia/hypoglycemia) deprivation studies. Cerebrocortical cells were plated onto 96-well, PEI coated culture plates using DME/F12 medium containing 10\% horse and $6 \%$ fetal bovine serum (heat inactivated). Non-neuronal cell division was halted $3 \mathrm{~d}$ into culture by adding $25 \mu \mathrm{g} / \mathrm{ml}$ uridine and $10 \mu \mathrm{g} / \mathrm{ml} 5$-fluoro-2'-deoxyuridine. Oxygen/glucose deprivation in cultures were carried out according to Weber et al. (1993). Briefly, culture growth media was removed and replaced with defined media and then cultures were deprived of oxygen and glucose for $0-330 \mathrm{~min}$ (exposure atmosphere: in triple gas incubator, $1 \% \mathrm{O}_{2}, 8 \% \mathrm{CO}_{2}, 91 \% \mathrm{~N}_{2}$; for exposure medium, $1.8 \mathrm{~mm}$ $\mathrm{Ca}^{2+}, 0.8 \mathrm{~mm} \mathrm{Mg}{ }^{2+}, 0.2 \mathrm{gm} /$ liter D-glucose; for normoxic condition, $\left.21 \% \mathrm{O}_{2}, 8 \% \mathrm{CO}_{2}, 71 \% \mathrm{~N}_{2}\right)$. After the deprivation interval, cells were either placed back in the normoxic conditions until $24 \mathrm{hr}$ postexperiment initiation for $\mathrm{LDH}$ measurement or used immediately for ${ }^{45} \mathrm{Ca}^{2+}$ determinations.

\section{Results and Discussion}

NMDA receptors appear to participate in the process of excitotoxicity and neuronal death. The hallmark of NMDA-induced neuronal death is a sustained increase in the $\left[\mathrm{Ca}^{2+}\right]_{i}$ and overactivation of vital $\mathrm{Ca}^{2+}$-dependent cellular enzymes such as calpain and CamK-II. Calpain overactivation with the presence of high $\left[\mathrm{Ca}^{2+}\right]_{i}$ following NMDA receptor (NMDAR) overstimulation leads to breakdown of structural proteins (e.g., spectrin) and proteolysis of other cellular substrates (Siman and Noszek, 1988; Saido et al., 1994). Specific inhibitors of calpain have proved to be neuroprotectant in EAA-induced neurotoxicity (for review, see Saido et al., 1994; Wang and Yuen, 1994). On the other hand CamK-II is vital in maintaining synaptic excitability through its multifunctional property. Interestingly autophosphorylated CamK-II is a substrate for activated calpain, which proteolytically fragments and produces an active and calcium-independent form of CamK-II (Kwiatkowski and King, 1989). To our knowledge, there have been no reports on examining specific inhibition of CamK-II in NMDA- and hypoxia/hypoglycemiainduced neurotoxicity in vitro.

To assess the degree of EAA-induced neuronal injury, we 


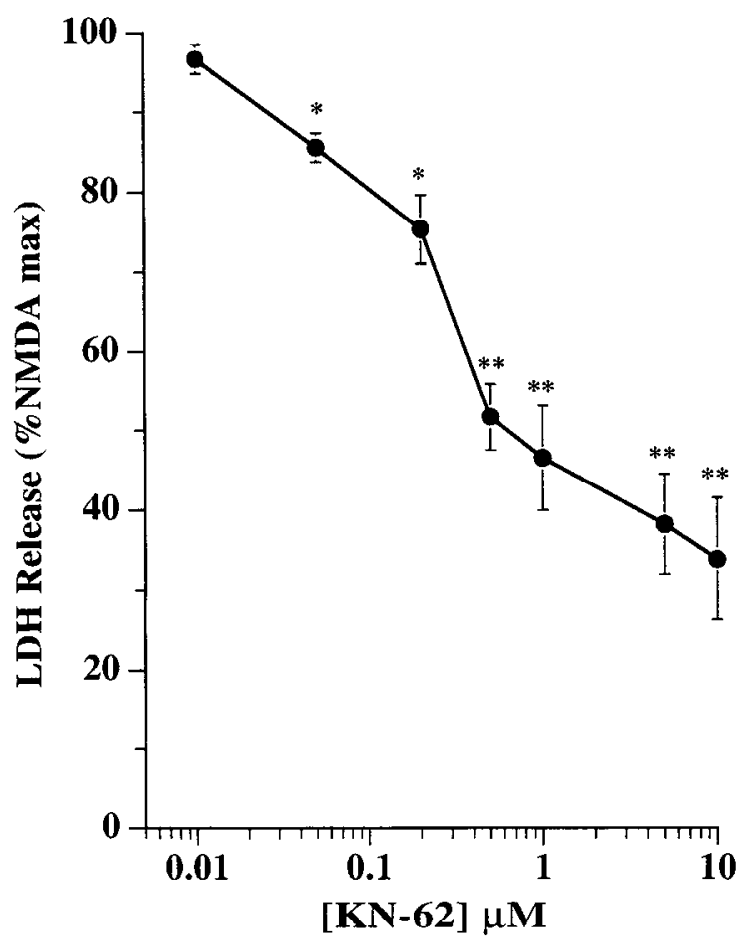

Figure 2. Concentration-response relationship of KN-62 against 250 $\mu \mathrm{M}$ NMDA toxicity. The final concentration of DMF in cultures used either as the solvent control or in $\mathrm{KN}-62$ solution is $0.1 \%$, except for $10 \mu \mathrm{M} \mathrm{KN}-62$ where the solvent concentration was $0.2 \%$. Data are means \pm SEM from three separate experiments. KN-62 was administered as pre-co-post treatment. ${ }^{* *}, p \leq 0.0001 ;{ }^{*}, p \leq 0.001$, Student's $t$ test (compared to NMDA alone).

measured the activity of the cytoplasmic enzyme, lactate dehydrogenase (LDH) released in the media (Koh and Choi, 1987); immunodetection of proteolytic fragments (150 and $145 \mathrm{kDa})$ of the cytoskeletal protein $\alpha$-fodrin (spectrin; $240 \mathrm{kDa}$ ) as produced by calpain (Siman and Noszek, 1988), and morphology by light microscopy. Previous work by others have shown a good correlation between neuronal death (by dye-exclusion method) and LDH measurements (Koh and Choi, 1987; Goldberg et al., 1987).

Pretreatment ( $1 \mathrm{hr}$ ) with $\mathrm{KN}-62(5 \mu \mathrm{M})$ offered a significant reduction $(65 \%)$ in $\mathrm{LDH}$ release, $24 \mathrm{hr}$ following application of 125 and $250 \mu \mathrm{M}$ NMDA (30 min at $37^{\circ} \mathrm{C}$ ) (Fig. $1 A$ ). Neuroprotection achieved by KN-62 was robust when, administered $1 \mathrm{hr}$ before NMDA application and included throughout the postincubation period ( $24 \mathrm{hr}$ ). However, we observed a significant but marginal protection (reduction in LDH release) against NMDA toxicity with KN-62 pretreatment only; neither simultaneous administration with NMDA nor post-NMDA application only of KN-62 was neuroprotective (Fig. IB). In comparison, competitive NMDA receptor antagonist $3-[( \pm)$-2-carboxypiperazine4-yl]propyl-1-phosphonic acid (CPP) at $100 \mu \mathrm{M}$ was highly neuroprotective in all treatment paradigms as expected (Fig. 1B). Furthermore, both biochemical (LDH activity and spectrin immunoblot) and morphological data show preservation of neurons by $\mathrm{KN}-62$ when acutely treated with NMDA (Fig. $1 B-D$ ). In the same toxicity paradigm, prior exposure of cultures to the protein phosphatase inhibitor okadaic acid (100nM) abolished the neuroprotective effects of $\mathrm{KN}-62$ (data not shown), which agrees with, the binding characteristics of $\mathrm{KN}-62$ to the non-
Table 1. Effect of various kinase inhibitors on NMDA-induced toxicity

\begin{tabular}{lcc} 
& \multicolumn{3}{c}{ LDH release (\% NMDA max) } \\
\cline { 2 - 3 } & NMDA $125 \mu \mathrm{M}$ & NMDA 250 $\mu \mathrm{M}$ \\
\hline KN-62 $(5 \mu \mathrm{M})(12)$ & $38.4 \pm 15.0^{* *}$ & $33.3 \pm 6.8^{* *}$ \\
Compound $5(5 \mu \mathrm{M})(5)$ & $49.9 \pm 13.5^{* *}$ & $80.1 \pm 10.6^{*}$ \\
Genistein $(5 \mu \mathrm{M})(3)$ & - & $109.1 \pm 7.6$ \\
Calphostin C $(0.25 \mu \mathrm{M})(3)$ & $136.1 \pm 5.0^{*}$ & $124.9 \pm 7.1^{*}$ \\
K252a $(0.5 \mu \mathrm{M})(3)$ & $109.4 \pm 31.6$ & $119.4 \pm 26.3$ \\
Calmidazolium $(5 \mu \mathrm{M})(3)$ & $105.0 \pm 21.1$ & $157.6 \pm 38.4^{*}$
\end{tabular}

All inhibitors were present throughout the experiment and also as a 1 hr pretreatment. LDH samples were taken $24 \mathrm{hr}$ following the NMDA challenge ( 30 $\min$ at $\left.37^{\circ} \mathrm{C}\right)$. The data are means $\pm \mathrm{SEM}$ from three or more separate experiments (number in parentheses). Concentrations of agents other than KN-62 used here were taken from published data in neuronal systems that provided effective inhibition. Compound 5 [2-hydroxyl-5-(2,5-dihydroxy-benzyl)aminobenzoic acid; O'Dell et al., 19911, K252a (Nocardiopsis sp.), calphostin C (Cladosporium cladosporioids), calmidazolium, and genistein (O'Dell et al., 1991) were purchased from LC Laboratories, and KN-62 was purchased from Seikagaku America, Inc. *, $P \leq 0.05$; **, $P \leq 0.0001$, Student's $t$ test

autophosphorylated CamK-II and the importance protein phosphorylation in such a parameter.

Neuroprotection observed with KN-62 against $250 \mu \mathrm{M}$ NMDA-induced toxicity was concentration-dependent, being most effective at $0.5-10 \mu \mathrm{M}$ (Fig. 2). This is in agreement with previous reports using $\mathrm{KN}-62$ in cell-based systems (Tokumitsu et al., 1990; Hidaka and Hagiwara, 1992; Hack et al., 1993; Figurov et al., 1993). Effective concentrations of KN-62 (0.5$10 \mu \mathrm{M}$ ) against NMDA-induced toxicity observed in this study have been shown to provide $7580 \%$ inhibition of CamK II ac tivity in the exogenous substrate phosphorylation (Tokumitsu et al., 1990).

The effect of KN-62 appears to be selective since, calmidazolium (a calmodulin antagonist), genistein (a tyrosine protein kinase inhibitor), K252a (a nonspecific protein kinase inhibitor) and calphostin $\mathrm{C}$ (a PKC inhibitor) were not neuroprotective against 125 and $250 \mu \mathrm{M}$ NMDA challenge (Table 1). Calmidazolium and calphostin $\mathrm{C}$, at concentrations used here and mode of application (pre/co/post), exacerhated NMDA-induced toxicity (Table 1). However, compound 5 (a mixed tyrosine kinase and CamK-II inhibitor) produced a significant protection against both doses of NMDA tested (Table 1). The lower degree of protection observed by compound 5 could be due to its lack of binding specificity to CamK-II as compared to KN-62. It would be ideal to have highly specific inhibitors like KN-62 (which does not compete with ATP) for the major classes of protein kinases (e.g., PKA and PKG) to test in such excitotoxicity paradigms. The availability of such compounds will allow one to determine the components involved, and also test combination strategies, in this model of neuronal death.

To complement these studies, the ability of $\mathrm{KN}-62$ to protect neurons in an oxygen/glucose-deprivation (hypoxia/hypoglycemia) induced neurotoxicity model in rat cortical cultures was examined. This in vitro model of neurotoxicity has previously been shown to be primarily mediated through the NMDA receptor and can be blocked effectively by NMDA antagonists (Choi, 1987, 1988; Marcoux et al., 1990; Goldberg and Choi, 1993; Hartley et al., 1993; Weber et al., 1993). Neuronal degeneration in this type of insult is similar to those associated with partial focal cerebral ischemia in vivo (e.g., middle cerebral artery occlusion in rat). Oxygen/glucose deprivation interval of 


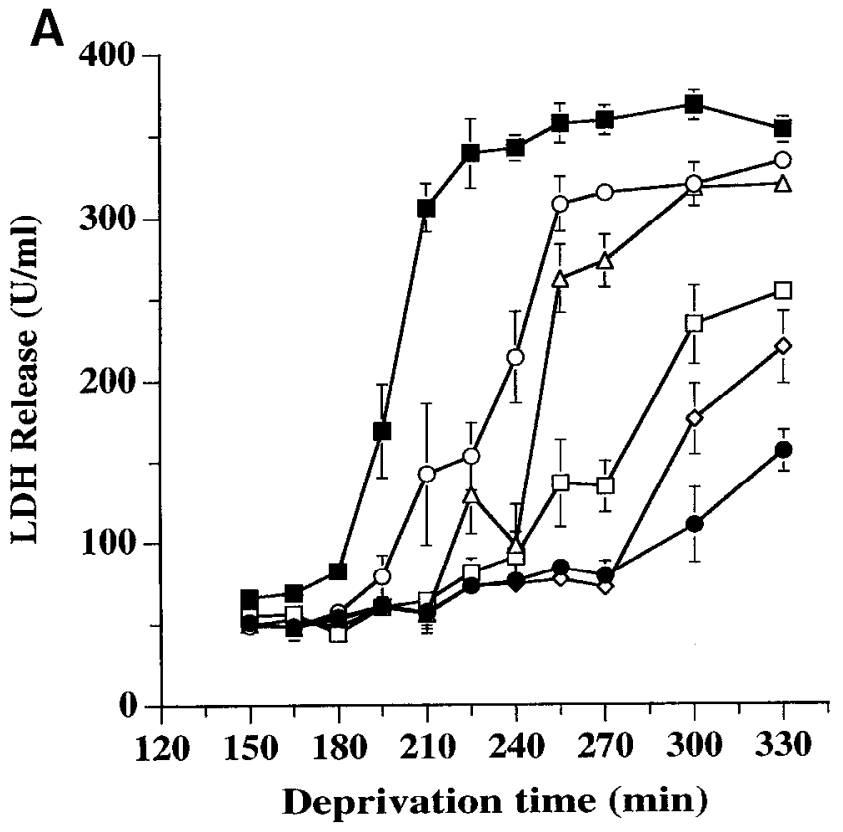

B

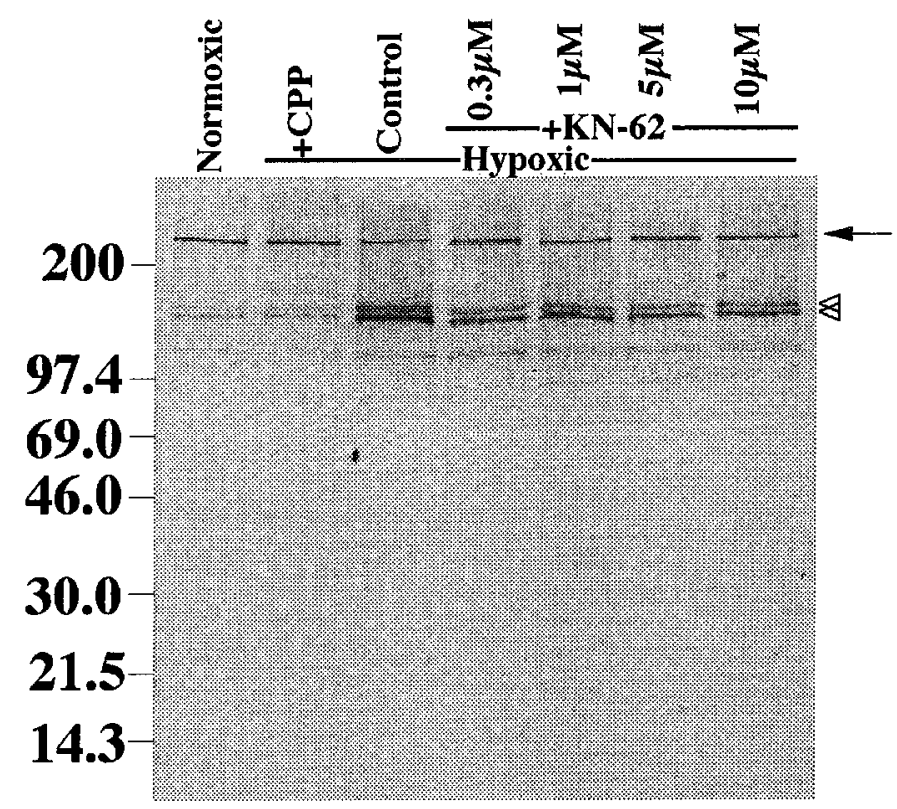

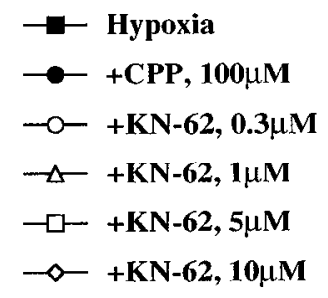

Figure 3. Inhibition of oxygen/glucose (hypoxia/hypoglycemia) deprivation-induced (labeled as hypoxia) neuronal death by $\mathrm{KN}-62(0.3-10 \mu \mathrm{M})$ and CPP $(100 \mu \mathrm{M}) . A, \mathrm{LDH}$ release with increasing duration of deprivation. Samples were taken $24 \mathrm{hr}$ post experiment initiation. Data are means \pm SEM from six observations. All data points from $180-300$ min were statistically significant compared to hypoxic control values with at least $p \leq 0.01$ (Student's $t$ test). $B$, Western blot analysis of proteins extracted from $240 \mathrm{~min}$ deprivation interval, probed with antispectrin antibody. molecular weight markers (kDa) are shown on the left. Solid arrow shows intact spectrin $(240$ $\mathrm{kDa}$ ) and open arrowheads show proteolytic breakdown fragments of spectrin (150 and $145 \mathrm{kDa})$.
$240 \mathrm{~min}(4 \mathrm{hr}$; followed by $24 \mathrm{hr}$ incubation in normoxic conditions) in our cultures produces maximum neuronal degeneration (Fig. 3). Pretreatment ( $1 \mathrm{hr}$ ) and continuous presence of $\mathrm{KN}$ 62 dose dependently and significantly reduced neurotoxicity in this model, as evaluated by $\mathrm{LDH}$ release and calcium accumulation (Figs. 3, 4B). Immunoblot of proteins (labeled with antispectrin antibody) extracted from $240 \mathrm{~min}$ of hypoxia/hypoglycemia condition show reduced proteolytic fragments of intact spectrin in KN-62 pretreated cultures compared to the appropriate control (Fig. 3B). However, immunoblots of spectrin and its proteolytic fragments, did not reflect the dose-response of $\mathrm{KN}$ 62 observed with the LDH release assay in this toxicity paradigm (Fig. 3B). This may be due to the qualitative rather than quantitative nature of spectrin immunoblots in such a protocol. Neuroprotection seen by KN-62 (at 5 and $10 \mu \mathrm{M}$ ) was effective up to $260 \mathrm{~min}$ of oxygen/glucose deprivation followed by $24 \mathrm{hr}$ in normoxic condition. The competitive NMDA antagonist CPP $(100 \mu \mathrm{M})$ produced almost complete protection against all deprivation intervals, as seen in $\mathrm{LDH}$ release (Fig. $3 A$ ) and calcium accumulation (Fig. 4B).

One common feature in NMDA or oxygen/glucose deprivation-induced toxicity is an increase in the level of intracellular free calcium $\left(\left[\mathrm{Ca}^{2+}\right]_{i}\right.$ ), which has been shown to correlate well with consequent (delayed) neuronal death (Choi, 1987, 1988; Marcoux et al., 1990; Goldberg and Choi, 1993; Hartley et al., 1993; Weber et al., 1993). KN-62 reduced calcium $\left({ }^{45} \mathrm{Ca}^{2+}\right)$ accumulation by $34-58 \%$ in NMDA toxicity and $10-100 \%$ in oxygen/glucose deprivation, depending on the degree of the insults (Fig. 4).

To further investigate the effect of $\mathrm{KN}-62$ on calcium influx, 


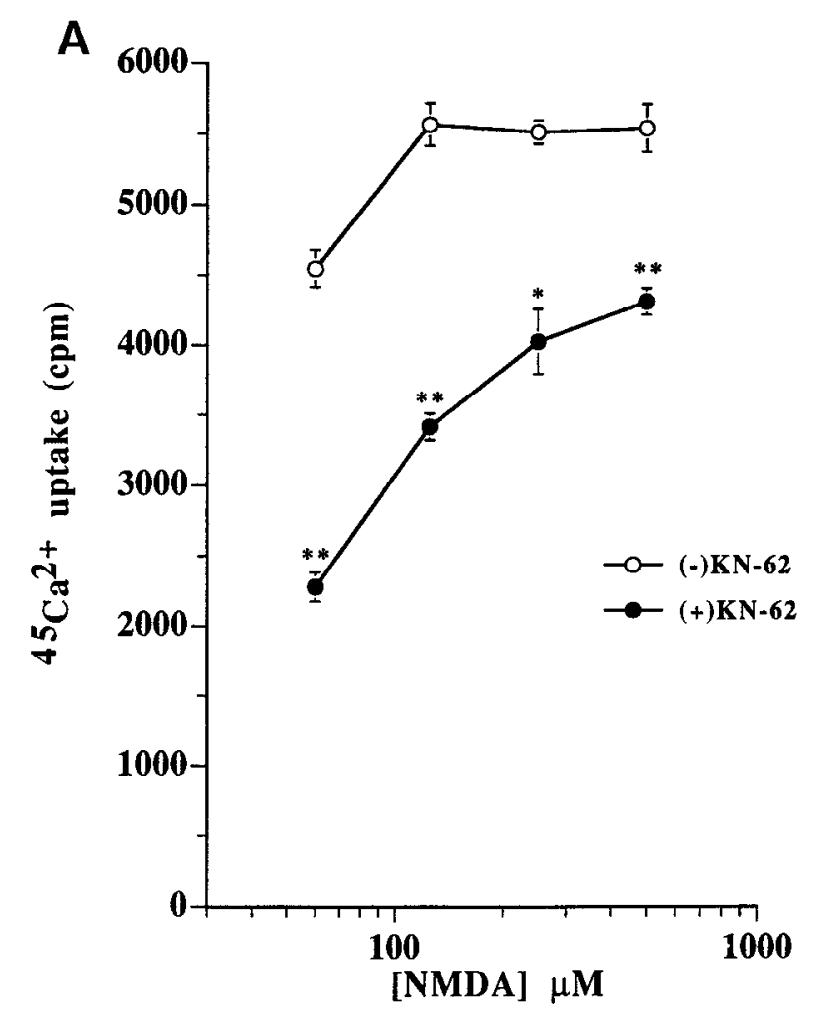

Figure 4. Calcium accumulation following NMDA challenge or oxygen/ glucose (hypoxia/hypoglycemia) deprivation. $A,{ }^{45} \mathrm{Ca}^{2+}$ uptake after NMDA (60-500 $\mu \mathrm{M}$ ) challenge for $30 \mathrm{~min}$ in presence or absence of $5 \mu \mathrm{M} \mathrm{KN}-62$ (1 hr pretreatment). ${ }^{* *}, p \leq 0.001 ; *, p \leq$ 0.01 , Student's $t$ test. $B,{ }^{45} \mathrm{Ca}^{2+}$ uptake with increasing duration of oxygen/glucose deprivation. Data are means \pm SEM of six to eight determinations. All data points from 165-300 min for CPP, $\mathrm{KN}-62$ (5 and $10 \mu \mathrm{M}$ ) and for $\mathrm{KN}-62$ $(0.3$ and $1 \mu \mathrm{M})$ from $165-225 \mathrm{~min}$, were statistically significant compared to hypoxic control values with at least $p \leq 0.01$ (Student's $t$ test).

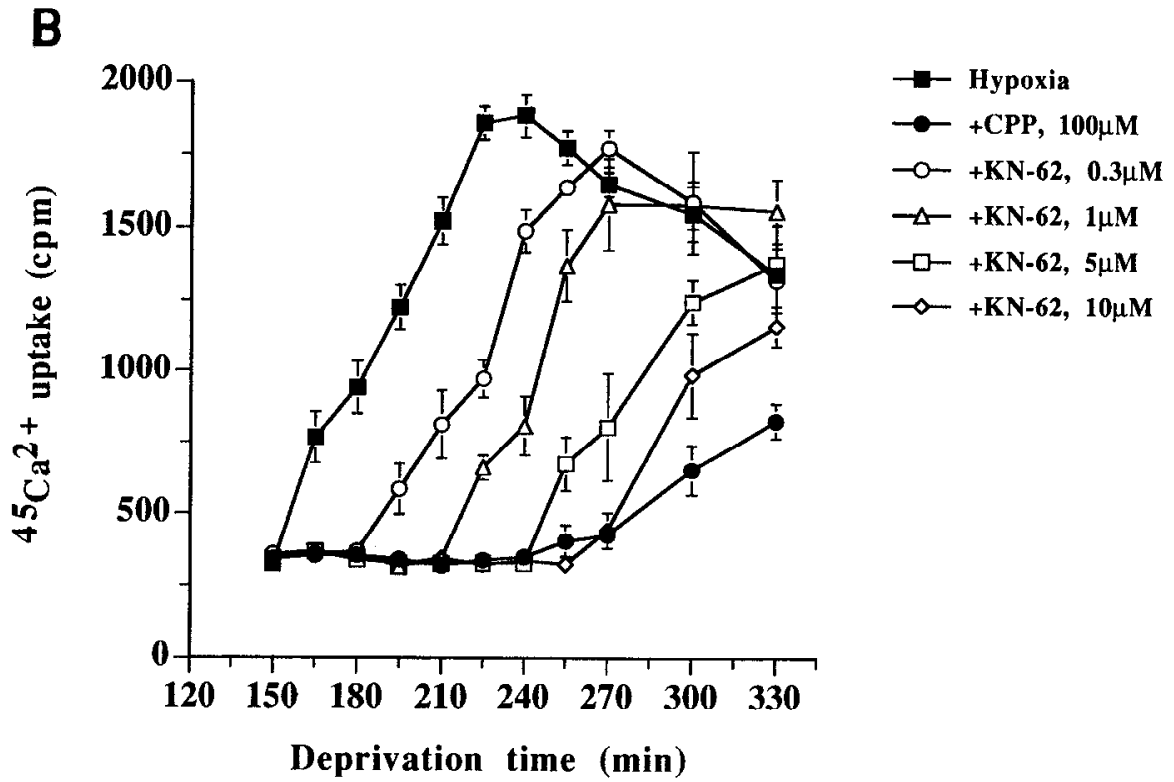

we employed Fura-2 microspectrofluorimetry to measure changes in free $\left[\mathrm{Ca}^{2+}\right]_{i}$ in single neurons following stimulation with NMDA in presence or absence of KN-62. Pretreating neurons with $5 \mu \mathrm{M} \mathrm{KN}-62$ for 30 min resulted in a $50.3 \%$ reduction in $\left[\mathrm{Ca}^{2+}\right]_{i}$ in response to $25 \mu \mathrm{M}$ NMDA for $1 \mathrm{~min}$ (Fig. 5, Table $2 A$ ). Furthermore $\mathrm{KN}-62$ pretreatment produces a similar reduction in $\left[\mathrm{Ca}^{2+}\right]_{i}$ in response to $100 \mu \mathrm{M}$ and $250 \mu \mathrm{M}$ NMDA (data not shown). However, quantitative analysis of $\left[\mathrm{Ca}^{2+}\right]_{i}$ becomes more difficult since neurons challenged with high concentrations of NMDA do not fully recover and show delayed secondary increases in $\left[\mathrm{Ca}^{2+}\right]_{i}$ (Tymianski et al., 1994). Interestingly the effect of $\mathrm{KN}-62$ on the $\left[\mathrm{Ca}^{2+}\right]_{i}$ response is most evident as a more rapid return to the basal level (Fig. 5), consistent with an action on the maintenance rather than the induction of elevated $\left[\mathrm{Ca}^{2+}\right]_{i}$. This conclusion was derived from an analysis of the peak height, and the duration of the half-maximal NMDA-induced calcium responses in neurons with and without $\mathrm{KN}-62$ pretreatment (Table $2 B$ ). The initial rise in $\left[\mathrm{Ca}^{2+}\right]_{i}$ was not re- 


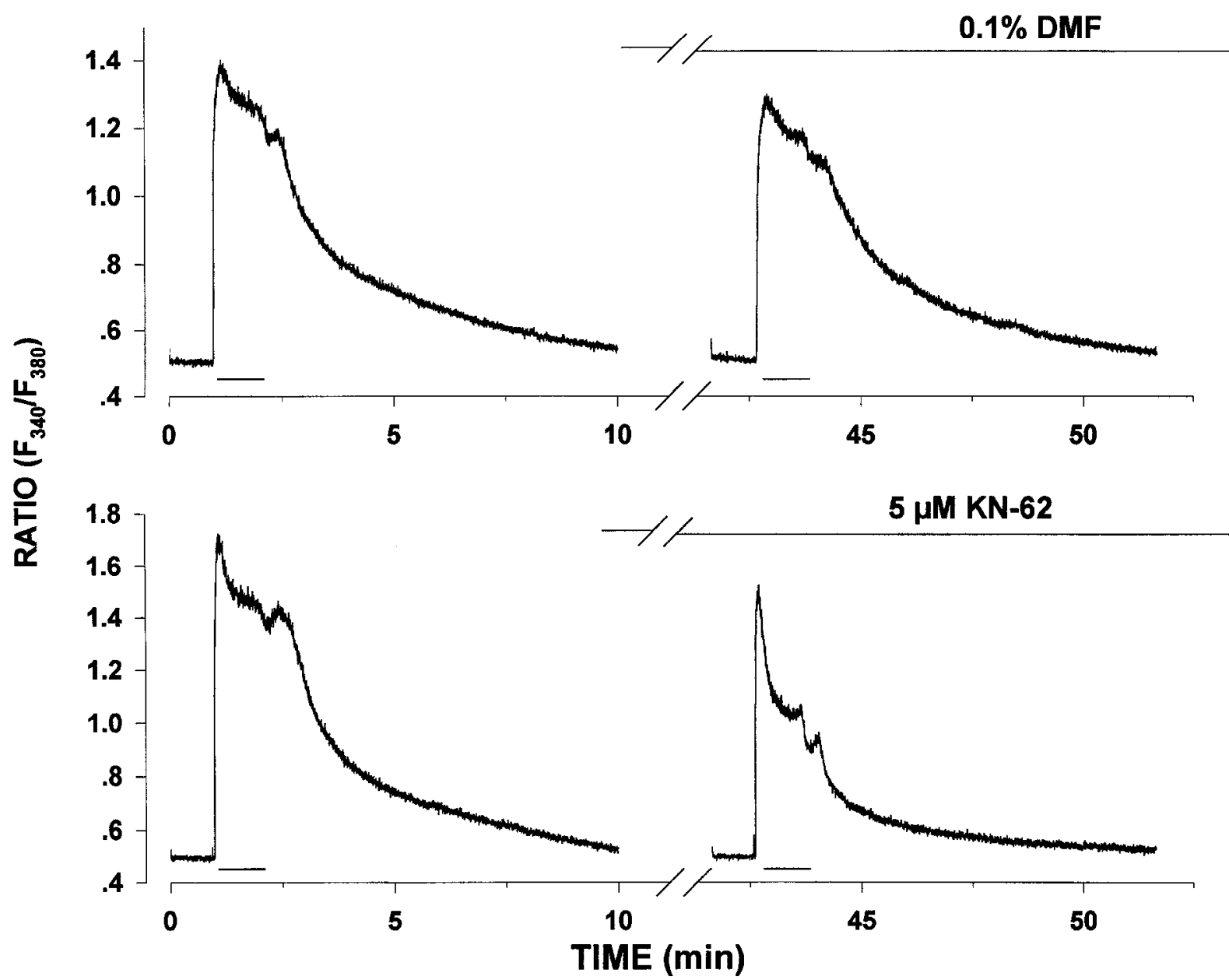

Figure 5. $\left[\mathrm{Ca}^{2+}\right]_{i}$ measurement in single neurons. A representative Fura-2 fluorescence ratio $\left(F_{340} / F_{380}\right)$ versus time waveform in response to 25 $\mu \mathrm{M}$ NMDA with $30 \mathrm{~min} \mathrm{KN}-62(5 \mu \mathrm{M})$ or vehicle pretreatment. Second challenge with NMDA ( $25 \mu \mathrm{M})$ is indicated by zero (min) in the trace. For full analysis of data see Table 2. Small bars indicate 1 min NMDA $(25 \mu \mathrm{M})$ application. First NMDA challenge not shown.

duced by $\mathrm{KN}-62$ pretreatment, while there was a significant decrease in the half recovery time (Table $2 B$ ). The reduction in $\left[\mathrm{Ca}^{2+}\right]_{i}$ could not be shown when $\mathrm{KN}-62$ was only administered with NMDA (Table $2 A$ ) ruling out a direct effect of this compound on the NMDA receptor or other modulatory/regulatory sites on the plasma membrane.

To further eliminate the possibility of KN-62 interacting with glutamate receptor subtypes at the level of the plasma membrane, we examined $\mathrm{KN}-62(1$ and $5 \mu \mathrm{M})$ in radioligand binding assays in rat brain membrane for glutamate, glycine, TCP (a noncompetitive NMDA channel binding site), AMPA and kainate. At $1 \mu \mathrm{M}, \mathrm{KN}-62 \mathrm{had}$ no effect in any of the ligand binding sites. However at $5 \mu \mathrm{M}, \mathrm{KN}-62$ slightly but significantly increased the ${ }^{3} \mathrm{H}$-glutamate binding (Table 3 ). These observations

\section{Table 2. Effect of KN-62 on NMDA-induced changes in $\left[\mathrm{Ca}^{2+}\right]_{\mathrm{i}}$ in single neurons}

DMF $\quad \mathrm{KN}-62(5 \mu \mathrm{M})$

A. \% Control (NMDA $25 \mu \mathrm{M})$

$\left(F_{340} / F_{380}\right.$ vs time $)$

Pretreatment $(30 \mathrm{~min})$

Coapplication

B. \% Reduction (pretreatment)
Peak height
Half-recovery time

$\begin{aligned} 99.2 \pm 4.3(9) & 51.0 \pm 2.9^{* *}(11) \\ 85.7 \pm 1.5(10) & 83.8 \pm 1.8 \quad(10) \\ & \\ 14.4 \pm 1.4(11) & 18.1 \pm 1.7 \quad(9) \\ 1.6 \pm 1.9(11) & 34.9 \pm 2.5^{* *}(9)\end{aligned}$

Data are means \pm SEM. Numbers of neurons examined for each condition are in parentheses. For section A results were quantified by measuring the area under the curve of the fluorescence ratio versus time waveform (see also Fig. 5). DMF, dimethyl formamide (used to prepare $5 \mathrm{mM}$ stock solution of KN-62). Section B presents analysis of peak heights and duration of the half-maximal NMDA-induced calcium responses in neurons pretreated with DMF $(0.1 \%)$ or KN-62 $(5 \mu \mathrm{M})$, as percentage reduction in these parameters between the second and first NMDA challenge (see Fig. 5). Half-recovery time is the time taken between $50 \%$ of the peak height on the rising and falling phase of the NMDA-induced increase in $\left[\mathrm{Ca}^{2+}\right]_{.} * *, P \leq 0.0001$, Student's $t$ test. 
Table 3. Effect of KN-62 on glutamate receptor-related ligand binding

$\%$ of control binding $\left({ }^{3} \mathrm{H}\right)$

\begin{tabular}{lllllll} 
& & & & & \\
& & & & & \\
& Glutamate & Glycine & Basal & Glu/Gly & AMPA & Kainate \\
\hline KN-62 $1 \mu \mathrm{M}$ & $105.9 \pm 3.9$ & $114.3 \pm 30.4$ & $98.4 \pm 8.8$ & $97.5 \pm 5.8$ & $90.7 \pm 10.6$ & $90.6 \pm 3.1$ \\
KN-62 $5 \mu \mathrm{M}$ & $118.6 \pm 4.8 *$ & $118.9 \pm 15.2$ & $91.1 \pm 8.0$ & $90.4 \pm 10.2$ & $99.9 \pm 10.3$ & $94.2 \pm 5.2$ \\
\hline
\end{tabular}

Data are mean $\pm \mathrm{SD}$ of three experiments. ${ }^{*}, P \leq 0.01$, Student's $t$ test.

strengthen our hypothesis that CamK-II is modulating NMDA channel activity directly or indirectly by a protein phosphorylation pathway rather than a direct physical interaction with the receptor proper. The significance of the increase in the glutamate binding with $5 \mu \mathrm{M} \mathrm{KN}-62$ is unclear.

The observation that pretreatment with $\mathrm{KN}-62$ is necessary in reducing both the increase of $\left[\mathrm{Ca}^{2+}\right]_{i}$ (Table 2) and NMDA-induced excitotoxicity (Fig. $1 B$ ) indicates that the neuroprotective effects of this compound are mediated by an intracellular mechanism. Such a mechanism is most likely through the inhibition of CamK-II (due to the high specificity of KN-62 on CamK-II). Furthermore, with the assumption that the neuroprotective effects of KN-62 can be attributed to the inhibition of CamK-II, it would mean that CamK-II normally has a positive modulatory effect on NMDA-mediated calcium accumulation. The NMDA receptor itself, voltage-sensitive calcium channels or other mechanisms regulating calcium mobilization are potential targets of CamK-II.

In the event of excitotoxicity or ischemia, one can envision a positive feedback mechanism: overstimulation of NMDA receptor results in calcium influx and the activation of CamK-II which in turn potentiates cellular calcium overload by phosphorylating and enhancing NMDA receptor function and/or other factors involved. It is clear, however, that CamK-II inhibition does not provide a complete blockade of NMDA-mediated neurotoxicity (Figs. 1, 2), indicating that such an insult is multifactorial.

The subunit of NMDA receptor (NMDARl) essential for forming a functional receptor channel is a 938 amino acid protein with putative phosphorylation sites for PKC in the C-tcrminal cytosolic region (Ishii et al., 1993). Upon phosphorylation by PKC calcium current through the NMDA receptor is enhanced by removing the voltage-dependent $\mathrm{Mg}^{2+}$ block (Chen and Huang, 1992). According to the rat NMDAR1 sequence by Ishii et al. (1993), amino acid residues 880-883 (Arg-Ala-IleThr) N-terminal from the PKC phosphorylation domain (902907), fits the consensus phosphorylation sites for CamK-II (Arg/ Lys-Xxx-Yyy-Ser/Thr) (Schulman and Hanson, 1993). Thus it is possible that, NMDA-mediated calcium influx is regulated by phosphorylation of this regulatory domain of NMDAR 1 by CamK-II.

Besides the NMDA receptor, several other factors which may participate in NMDA neurotoxicity and be influenced by CamKII are presynaptic release of glutamate, AMPA/kainate ionotropic channel activity, voltage-gated calcium channels, and production of second messengers like nitric oxide. One can speculate that inhibition of CamK-II by KN-62 will also provide neuroprotection against non-NMDA (AMPA and kainate) receptor mediated neuronal injury, since there is direct evidence for positive modulation of AMPA mediated responses by CamK-II (Tan et al., 1994). We are currently testing out these hypotheses in neuronal cultures. Further work is also needed to test $\mathrm{KN}-62$ and/or related compounds in in vivo models of neurotoxicity (ischemia/stroke). The findings in this study provide clear evidence that inhibition of CamK-II can alter the course of NMDA-mediated excitotoxicity and this protein kinase may play a critical role in processes involved with neuronal pathophysiology.

\section{References}

Birrell GJ, Gordon MP, Marcoux FW (1993) (1S,3R)-1-aminocyclopentane-1,3-dicarboxylic acid attenuates $N$-methyl-D-aspartate-induced neuronal cell death in cortical cultures via a reduction in delayed $\mathrm{Ca}^{2+}$ accumulation. Neuropharmacol 32:1351-1358.

Chen L. Huang LYM (1992) Protein kinase C reduces magnesium block of NMDA-receptor channels as a mechanism of modulation. Nature 356:521-523.

Choi DW (1987) Ionic dependence of glutamate neurotoxicity in cortical cell culture. J Neurosci 7:369-379.

Choi DW (1988) Glutamate neurotoxicity and diseases of the nervous system. Neuron 1:623-634.

Churn SB, Taft WC, Billingsley MS, Sankaran B, DeLorenzo RJ (1992) Global forebrain ischemia induces a posttranslational modification calciun- and calnodulin-dependent kinase II. J Neurochem 59:12211232.

Churn SB, Sombati S, Taft WC, DeLorenzo RJ (1993) Excitotoxicity affects membrane potential and calmodulin kinase II activity in cultured rat cortical neurons. Stroke 24:271-278.

Figurov A, Boddeke H, Muller D (1993) Enhancement of AMPAmediated synaptic transmission by the protein phosphatase inhibitor calyculin A in rat hippocampal slices. European. J Neurosci 5: 10351041 .

Fukunaga K, Soderling TR (1990) Activation of calcium/calmodulindependent kinase II in cerebellar granule cells by $N$-methyl-D-aspartate receptor activation. Mol Cell Neurosci 1:133-138.

Fukunaga K, Soderling TR, Miyamoto E (1992) Activation of calcium/ calmodulin-dependent protein kinase II and protein kinase $\mathrm{C}$ by glutamate in cultured rat hippocampal neurons. J Biol Chem 267:2252722533.

Goldberg MP, Choi DW (1993) Combined oxygen and glucose deprivation in cortical cell culture: calcium-dependent and calcium-independent mechanism of neuronal injury. J Neurosci 13:3510-3524.

Goldberg MP, Weiss JH, Pham PC, Choi DW (1987) N-Methyl-D-aspartate receptors mediate hypoxic neuronal injury in cortical cultures. J Pharmacol Exp Ther 243:784-791.

Greengard P, Jen J, Nairn AC, Stevens CF (1991) Enhancement of the glutamate response by cAMP-dependent protein kinase in hippocampal neurons. Science 253:1135-1138.

Greengard P, Valtorta F, Czernik $\Lambda J$, Benfenati F (1993) Synaptic vesicle phosphoproteins and regulation of synaptic function. Science 259:780-785

Hack N, Hidaka H, Wakefield MJ, Balazs R (1993) Promotion of granule cell survival by high $\mathrm{K}^{+}$or excitatory amino acid treatment and calcium/calmodulin-dependent protein kinase activity. Neuroscience 57:9-20.

Hanson SK, Grotta JC, Waxham MN, Aronowski J, Ostrow P (1994) Calcium/calmodulin-dependent kinase II activity in focal ischemia with reperfusion in rats. Stroke 25:466-473.

Hartley DM, Kurth MC, Bjerkness L, Weiss JH, Choi DW (1993) Glutamate receptor-induced ${ }^{45} \mathrm{Ca}^{2+}$ accumulation in cortical cell culture correlates with subsequent neuronal degeneration. J Neurosci 13: $1993-2000$ 
Hidaka H, Hagiwara M (1992) Advances in second messenger and phosphoprotein research, pp 241-248. New York: Raven.

Ishii T, Moriyoshi K, Sughihara H, Sakurada K, Kadotani H, Yokoi M, Akazawa C, Shigemoto R, Mizuno N, Masu M, Nakanishi S (1993) Molecular characterization of the family of the $N$-methyl-D-aspartate receptor subunits. J Biol Chem 268:2836-2843.

Keller BU, Hollmann M, Heinemann S, Konnerth A (1992) Calcium influx through subunits GluRI/GluR3 of kainate/AMPA receptor channcls is regulated by cAMP dependent protein kinase. EMBO J 11:891-896.

Kishimoto H, Simon JR, Aprison MH (1981) Determination of the equilibrium dissociation constants and number of glycine binding sites in several areas of the rat central nervous system, using a sodium-independent system. J Neurochem 37:1015-1024.

Kitamura Y, Miyazaki A, Yamanaka Y, Nomura Y (1993) Stimulatory effects of protein kinase $\mathrm{C}$ and calmodulin kinase II on $N$-methyl-Daspartate receptor/channels in the postsynaptic density of rat brain. J Neurochem 61:100-109.

Koh JY, Choi DW (1987) Quantitative determination of glutamate mediated cortical ncuronal injury in cell culture by lactate dehydrogenase efflux assay. J Neurosci Methods 20:83-90.

Kwiatowski AP, King MM (1989) Autophosphorylation of the type II calmodulin-dependent kinase is essential for formation of a proteolytic fragment with catalytic activity. Implications for long-term synaptic potentiation. Biochemistry 28:5380-5385.

Laemmli UK (1970) Cleavage of structural proteins during the assembly of the head of bacteriophage T4. Nature 227:680-685.

Lipton SA, Rosenberg PA (1994) Fxcitatory amino acids as final $\mathrm{com}-$ mon pathway for neurological disorders. New Engl J Med 330:613622.

Llinas R, McGuinness TL, Leonard CS, Sugimori M, Greengard P (1985) Intraterminal injection of synapsin I or calcium/calmodulindependent kinase II alters neurotransmitter release at the squid giant synapse. Proc Natl Acad Sci USA 82:3035-3039.

Malenka RC, Kauer JA, Perkel DJ, Mauk MD, Kelly PT, Waxham MD (1989) An essential role for postsynaptic calmodulin and protein kinase activity in LTP. Nature 340:554-557.

Marcoux FW, Probert AW, Weber ML (1990) Hypoxic neuronal injury in tissue culture is associated with delayed calcium accumulation. Stroke 2 I [Suppl III]:71-74.

McGlade-McCulloh E, Yamamoto H, Tan SE, Brickey DA, Soderling TR (1993) Phosphorylation and regulation of glutamate receptors by calcium/calmodulin-dependent kinase II. Nature 362:640-642.

Meldrum B, Garthwaite J (1990) Excitatory amino acid neurotoxicity and neurodegenerative disease. Trends Pharmacol Sci 11:379-387.
Nakamishi S (1992) Molecular diversity of glutamate receptors and implications for brain function. Science 258:597-603.

O'Dell TJ, Kandel ER, Grant SGN (1991) Long-term potentiation in the hippocampus is blocked by tyrosine kinase inhibitors. Nature 353 : $558-560$.

Raymond LA, Blackstone CD, Huganir RL (1993) Phosphorylation and modulation of recombinant GluR6 glutamate receptors by cAMPdependent protein kinase. Nature 361:637-641.

Rich DP, Schwober CM, Colbran RJ, Soderling TR (1990) Protenlytic activation of calcium/calmodulin-dependent protein kinase II: putative function in synaptic plasticity. Mol Cell Neurosci 1:107-116.

Saido TC, Sorimachi H, Suzuki K (1994) Calpain: new perspectives in molecular diversity and physiological-pathological involvement. FASEB J 8:814-822

Schulman H, Hanson PI (1993) Multifunctional calcium/colmodulindependent protein kinase. Neurochem Res 18:65-77.

Seeburg PH (1993) The molecular biology of mammalian glutamate receptor channels. Trends Neurosci 16:359-365.

Siman R, Noszek JC (1988) Excitatory amino acids activate calpain I and induce structural protein breakdown in vivo. Neuron 1:279-287.

Tan SE, Wenthold RJ, Soderling TR (1994) Phosphorylation of AMPA-type glutamate receptors by calcium/calmodulin-dependent protein kinase II and protein kinase $\mathrm{C}$ in cultured hippocampal neurons. J Neurosci 14:1123-1129.

Tokumitsu H, Chijiwa T, Hagiwara M, Mizutani, Terasawa M, Hidaka $\mathrm{H}$ (1990) KN-62, 1-[N,O-bis(5-isoquinolinesulfonyl)- $N$-methyl-L-tyrosyll-4-phenylpiperazine, a specific inhibitor of calcium/calmodulindependent kinase II. J Biol Chem 265:4315-4320.

Towbin H, Staehelin T, Gordon J (1979) Electrophoretic transfer of proteins from polyacrylamide gels to nitrocellulose sheets: procedure and some applications. Proc Natl Acad Sci USA 76:4350-4354.

Tymianski M, Charlton MP, Carlen, PI, Tator CH (1994) Properties of neuroprotective cell-permeant calcium chelators: effect on $\left[\mathrm{Ca}^{2+}\right]_{i}$ and glutamate neurotoxicity in vitro. J Neurophysiol 72:1973-1992.

Wang KKW, Yuen P-W (1994) Calpain inhibition: an overview of its therapeutic potential. Trends Pharmacol Sci 15:412-419.

Wang L-Y, Slater MW, MacDonald JF (1991) Regulation of kainate receptors by cAMP-dependent protein kinase and phosphatases. Science 253:1132-1135.

Weber ML, Probert AW, Dominick MA, Marcoux FW (1993) Early ultrastructural injury in meuronal cell culture after hypoxia or combined oxygen and glucose deprivation: neuroprotection with 4-(3phosphonopropyl)-2-piperazinecarboxylic acid (CPP). Neurodegeneration 2:63-72

Yamamoto H, Fukunaga K, Lee K, Soderling TR (1992) Ischemiainduced loss of brain calcium/calmodulin-dependent protein kinase II. J Neurochem 58:1110-1117. 